Rev. Int. Contam. Ambie. 36 (4) 1011-1018, 2020

https://doi.org/10.20937/RICA.53532

\title{
SYNTHESIS AND CHARACTERIZATION OF TRANSITION ALUMINAS FROM RECYCLED SCRAP ALUMINIUM
}

\author{
Síntesis y caracterización de alúminas de transición a partir de desechos de aluminio reciclado
}

\author{
Rosa María RODRÍGUEZ ${ }^{1 *}$, Delia GUTIÉRREZ-CAMPOS ${ }^{2}$, Elvira SAAB ${ }^{2}$, \\ Norberto LABRADOR ${ }^{2}$, Xavier $\mathrm{HUNG}^{2}$ and Carlos PALMA ${ }^{2}$
}

\author{
${ }^{1}$ Departamento de Química, Universidad Metropolitana, Terrazas del Ávila, Edificio Corimón piso 3, Caracas, \\ Venezuela, Zona Postal 1070. \\ ${ }^{2}$ Departamento de Ciencia de los Materiales, Universidad Simón Bolívar, Valle de Sartenejas, Municipio Baruta, \\ Caracas, Venezuela, Zona Postal 1086. \\ *Author for correspondence: rrodriguez@unimet.edu.ve
}

Key words: cans, binder, raw material.

\begin{abstract}
The aim of this study was to develop an alternative methodology for the synthesis of transition aluminas, in order to reduce ecological costs by using recycled metal scrap as raw material (cans of soft drinks) and generate a product with high added value. The synthesis technique employed yielded a precursor comprised of $55.4 \%$ of bayerite, 41.2 $\%$ of boehmite, and ammonium salt, according the characterization performed with $\mathrm{X}$-ray diffraction and quantification by the Rietveld method. The ammonium chloride salt present is not relevant for the process, since given its solubility in water, it could be eliminated by successive washing. Scanning electron microscopy evaluations showed the presence of agglomerates of particles between 50 and $300 \mu \mathrm{m}$. A bimodal grain sizes distribution was detected during the laser granulometric test. Thermogravimetric analysis of the precursor indicated a $40.6 \%$ total weight loss at $1000^{\circ} \mathrm{C}$. The heat treatments at 350 and $750{ }^{\circ} \mathrm{C}$ of precipitates for 1,2 and $4 \mathrm{~h}$, produced various transition aluminas $(\gamma, \eta, \theta)$, which are products where value has been added and might have a potential use as binders in monolithic products, catalyst support, or additives for puzzolanic materials, among others.
\end{abstract}

Palabras clave: latas, aglutinante, materia prima.

\section{RESUMEN}

El objetivo de este estudio fue desarrollar una metodología alterna para sintetizar alúminas de transición, partiendo de aluminio reciclado como materia prima (latas de bebidas gaseosas), a fin de disminuir los efectos ecológicos de este tipo de desecho y generar un producto de alto valor agregado. Con el método de síntesis implementado se obtiene un precursor conformado en un $55.4 \%$ por bayerita, $41.2 \%$ por bohemita $\mathrm{y}$ el resto por sal de amonio, de acuerdo con los estudios de rayos $\mathrm{X}$ realizados y la cuantificación por el método de Rietveld. La sal cloruro de amonio generada no es relevante para el proceso manejado, ya que su alta solubildad en agua permite eliminarla por lavados sucesivos. Estudios realizados por microscopia electrónica de barrido muestran la presencia de partículas aglomeradas con tamaños de 50 a $300 \mu \mathrm{m}$. Utilizando ensayos de granulometría laser, se determinó una distribución bimodal del 
tamaño de grano. El análisis térmico indicó una pérdida de masa del $40.6 \%$ en peso respecto de la muestra inicial del precursor al llevar la muestra a temperaturas cercana a los $1000^{\circ} \mathrm{C}$. Tratamientos térmicos a 350 y $750{ }^{\circ} \mathrm{C}$ realizados al precipitado obtenido, manteniendo la temperatura durante 1,2 y $4 \mathrm{~h}$, permitieron obtener varias alúminas de transición $(\gamma, \eta, \theta)$, que son productos con valor agregado que tienen usos potenciales como aglutinantes para refractarios monolíticos, soportes catalíticos o aditivos como materiales puzolánicos.

\section{INTRODUCTION}

As a technological material, alumina represents a great opportunity, because its properties allow very diverse applications that can range from the food and pharma industry to the chemical and electronic industry. Alumina can undergo different polymorphic transformations depending on the conditions in which these transformations are carried out (West 2014): thermal and via precursors, which allow obtaining different crystalline phases called transition aluminas (Levin and Brandon 1998). Three large types of alumina are known industrially: metallurgical grade, ceramic grade and transition aluminas. This last group, due to its multiple crystallographic and allotropic forms, presents the greatest number of uses and applications (West 2014). These aluminas can be used as catalyst support in combination with other activated transition aluminas (De Souza et al. 2000), as well as cementitious material of interest for its use as high temperature refractory cement (Lee and Moore 1998).

The aim of this work is to determine a technological path that, starting with recycled aluminium in Venezuela (Vitalis 2015), allows obtaining transitional aluminas (Mahinroosta and Allahverdi 2018). An important point is the handling of the raw material (Gonzalo 2008) to be used in this process, which follows the global recycling trend instead of continuing with the degradation of the different ecological systems from which the different precursors can be obtained (Schlesinger 2007).

We propose the use of soft-drink cans (Adans et al. 2016), which have a high potential in terms of reducing, recycling and reusing (RRR). In general, the vast majority of materials, especially those of metallic type, can be recycled once their useful life is over, thus giving way to materials of the same nature or with some variation to satisfy the needs of the market without having to resort to the sources of the metal. Such is the case of aluminium for soft-drink cans, whose postconsumer deposits (used beverage cans, UBC) are of particular interest for the present study. According to the Venezuelan regulation COVENIN 2352-86, the aluminium content in these deposits should be in the order of $97 \%$ (Iesmat 2015). These products represent a source of aluminium of relatively high purity with a high potential for recycling or reuse (COVENIN 1986). In general, the vast majority of materials, especially those of metallic type, can be recycled once their useful life is over, giving way to materials of the same nature or with some variation to meet the needs of the market without resorting to metal sources (Meshram and Kumar 2018).However, since the production levels of transition aluminas are very limited (if not inexistent) in Venezuela, obtaining materials of this nature may represent an alternative both for the development of new technologies and for companies that seek to stock up on this type of material or any other that may act as a precursor. In summary, we propose a method of reusing metallic aluminium from waste to obtain ceramics material with added value.

\section{MATERIALS AND METHODS}

The experimental procedure included four steps (Fig. 1):

1. Synthesis of the precursor through precipitation in aqueous media at low temperature $\left(25^{\circ} \mathrm{C}\right.$, ambient temperature); heating of cans at $500^{\circ} \mathrm{C}$ for 45 min (López et al. 2018); dissolution in $\mathrm{HCl} ; \mathrm{pH}$ adjustment with ammonium hydroxide (Sharma 2003), and aging precipitates (De Souza 1990, Ahmedzeki et al. 2017).

2. Characterization of the precursor by X-ray diffraction (XRD): $10^{\circ}-90^{\circ}\left(0.02^{\circ} / \mathrm{seg}, \mathrm{CuK} \alpha\right), 35$ $\mathrm{KV}, 25 \mathrm{~mA}$; scanning electron microscopy/energy dispersive spectroscopy (SEM/EDS): secondary electrons, and particle size distribution (PSD): $0.02-2000 \mu \mathrm{m}$.

3. Thermogravimetric analysis (TGA) and thermogravimetric differential analysis (TDA), thermal treatment of the precursor in order to achieve transition aluminas.

4. Characterization of the resulting products. 


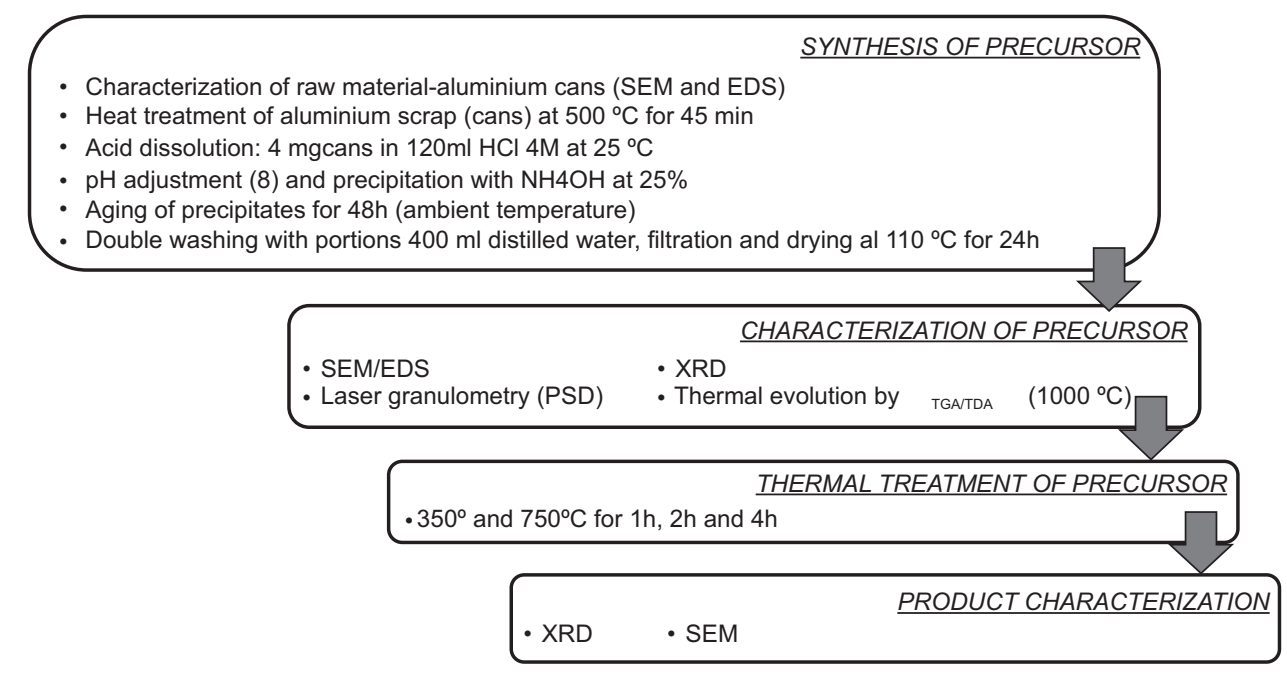

XRD: X-Ray Diffraction

PSD: Particle Size Distribution

SEM/EDS: Scanning Electron Microscopy/Energy Dispersive Spectroscopy

TGA/TDA: Thermogravimetric Analysis/Thermogravimetric Differential Analysis

Fig 1. Flowchart of the experimental procedure.

\section{RESULTS AND DISCUSSION}

Chemical composition analyses of the raw material (aluminium cans) and the precursor (precipitated material) were performed by SEM/EDS. The results (Table I) were as expected for both materials. Chlorine $(\mathrm{Cl})$ was detected in the precipitated precursor due to acid media dissolution with $\mathrm{HCl}$ and $\mathrm{pH}$ adjustment with ammonium hydroxide $\left(\mathrm{NH}_{4} \mathrm{OH}\right)$, as well as some reaction products according to the following formula:

$2 \mathrm{Al}_{(\mathrm{s})}+8 \mathrm{HCl}_{(\mathrm{aq})}+2 \mathrm{NH}_{4}(\mathrm{OH})_{(\mathrm{aq})} \rightarrow 2 \mathrm{AlCl}_{3(\mathrm{aq})}+$ $2 \mathrm{NH}_{4} \mathrm{Cl}_{(\mathrm{aq})}+3 \mathrm{H}_{2(\mathrm{~g})}+2 \mathrm{H}_{2} \mathrm{O}(\mathrm{l})$

TABLE I. CHEMICAL COMPOSITION OF ALUMINUM SCRAP AND PRECIPITATED PRECURSOR BY SCANNING ELECTRON MICROSCOPY/ ENERGY DISPERSIVE SPECTROSCOPY.

\begin{tabular}{ccc}
\hline Element (wt \%) & Raw material & Precursor \\
\hline $\mathrm{Mg}$ & 2.33 & - \\
$\mathrm{Al}$ & 96.24 & 87.76 \\
$\mathrm{Mn}$ & 0.87 & - \\
$\mathrm{Fe}$ & 0.57 & - \\
$\mathrm{Cl}$ & - & 12.24 \\
\hline
\end{tabular}

It is relevant to note that no metallic elements (like $\mathrm{Fe}$ or $\mathrm{Mn}$ ) were observed in the precursor, indicating that the controlled precipitation process could allow the synthesis of materials free of contaminants.

The precursor was characterized using different techniques: XRD, PSD and morphological assessment with SEM. Boehmite $(\gamma-\mathrm{AlOOH})$ and bayerite $\left(\alpha-\mathrm{Al}(\mathrm{OH})_{3}\right)$ were detected by XRD (Fig. 2). Both compounds are precursors phases of transition aluminas according to the sequences of phase transformations toward the stable $\alpha$-phase reported in literature (West 2014). Percentages of detected phases were estimated with the Rietveld technique and pseudoVoigt adjustment (Young 2002).

The composition of the precipitated precursor was $55.4 \%$ of bayerite, $41.2 \%$ of boehmite and $3.4 \%$ of ammonium salt. The PSD of the precursor (Fig. 3) indicates a bimodal distribution with two distinctive particle sizes, 68 and $500 \mu \mathrm{m}$, respectively (Iesmat 2015). The SEM evaluation (Fig. 4) revealed agglomerates with particle size ranging from 50 to 300 $\mu \mathrm{m}$, which confirmed the PSD performed with laser granulometer. Also, particles with sizes around $1 \mu \mathrm{m}$ were observed.

The thermal evolution of the precursor was studied through typical DTA/TGA methodologies (Smykatz-Kloss 1974). The dehydration appears to start at $106^{\circ} \mathrm{C}$ (Fig. 5a), indicated by 


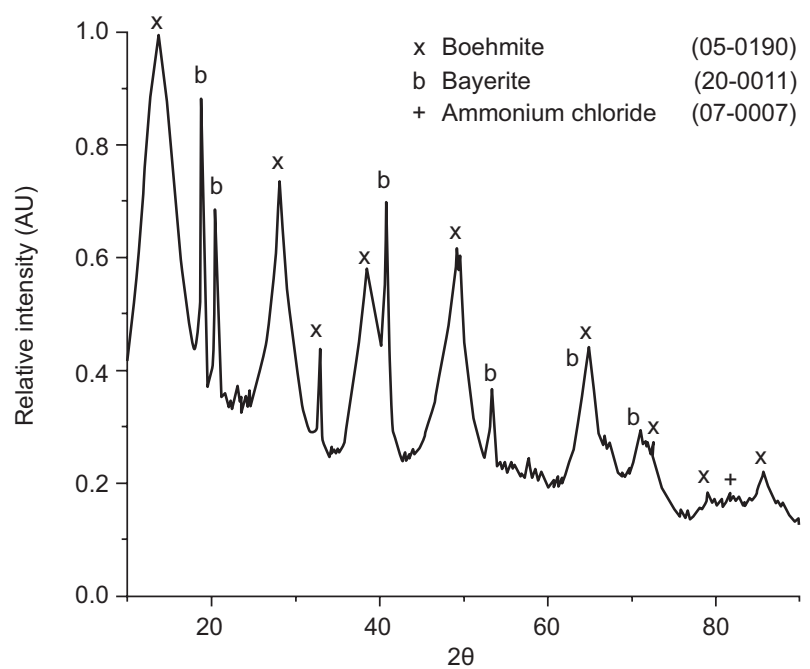

Fig. 2. X-ray diffraction of the precipitated precursor.

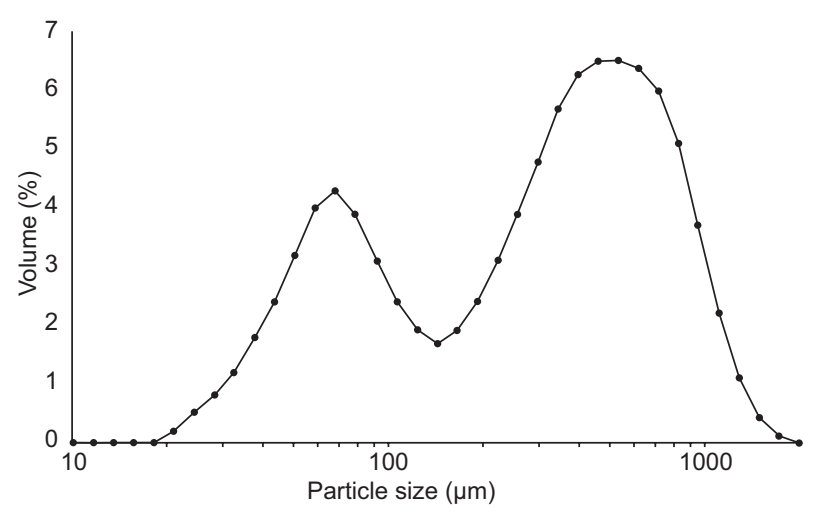

Fig. 3. Particle size distribution of the precursor.

the endotherm peak, and continues up to $145^{\circ} \mathrm{C}$, probably because the small capillarity of the gelatinous precursor slowed down the water loss through the material. This step accounts for $8 \%$ of the mass loss. A sharp exothermic peak appears at $225{ }^{\circ} \mathrm{C}$, which represents energy release during the transformation phase from bayerite to $\eta$-alumina (Sato 1962). Another step occurres between two endothermic peaks at 260 and $360^{\circ} \mathrm{C}$, which may be attributed to two events: elimination of residual hydroxyls and ammonium chloride decomposition. The exotherm that appears at $490{ }^{\circ} \mathrm{C}$ corresponds to the transformation of boehmite into $\gamma$-alumina (Alphonse and Courty 2005). Thermal evolution occurring between 190 and $750{ }^{\circ} \mathrm{C}$, approximately, account for $30 \%$ of mass loss (Fig. 5b).
Discrepancies between TDA and TGA curves may indicate that the change in enthalpy is not directly proportional to the rate of mass loss, which is normally encountered in complex reactions. However, in the present study, all the events observed during thermal evolution analysis were confirmed with Xray diffractograms at various temperatures of the precursor (Fig. 6).

Since transition aluminas could be prepared by calcining aluminium hydroxides, thermal treatment of the precursor was conducted at 350 and $750^{\circ} \mathrm{C}$ at a rate of $10^{\circ} \mathrm{C} / \mathrm{min}$ for $1 \mathrm{~h}$ and $4 \mathrm{~h}$ (Dwivedi 1985). The obtained product was characterized by XRD. Different kinds of transition alumina were obtained after the thermal treatment of the precursor: $\eta-\mathrm{Al}_{2} \mathrm{O}_{3}$ (Fig. 7a) and $\gamma-\mathrm{Al}_{2} \mathrm{O}_{3} \mathrm{O}-\mathrm{Al}_{2} \mathrm{O}_{3}$ (Fig. 7b).

In order to detect possible hydraulic activity of the obtained transition aluminas, heat-treated samples of synthesized product (at 350 and $750{ }^{\circ} \mathrm{C}$ ) were subjected to hydration with distilled water for $168 \mathrm{~h}$. Then the samples were washed with ethanol and prepared with gold for the observation in SEM model FEi Inspect F50. The comparison of morphological features (Fig. 8a, b) (heat-treated samples at $350^{\circ} \mathrm{C}$ ) reveals morphological changes of the transition aluminas after hydration. These transformations are correlated with those studied by Lefévre et al. 2002 and Sato 2007, who characterized this type of transformation for periods of 4 days, observing a transient amorphous hydrated phase, followed by an increase in bayerite concentration, which stabilizes after about two months. Thermodynamical calculations predict the hydration reaction of $\gamma$-alumina leading to a more stable phase (bayerite, gibbsite, or boehmite), since the surface reactivity and sorption properties of solids are factors controlling the transport of elements in water. This could be an indication of potential hydraulic activity due to the formation of new phases. In contrast, comparison of heat-treated samples at $750{ }^{\circ} \mathrm{C}$ and $168 \mathrm{~h}$ (Fig. 8c, d) with and without hydration, did not show any relevant difference in morphological features; thus, apparently this material does not present any hydraulic activity, at least under this conditions

Nanometric particles smaller than $100 \mathrm{~nm}$ (Fig. 9) were observed in the synthesized transition aluminas heat-treated at $350^{\circ} \mathrm{C}$. This shows that the synthesis technique could yield micro- and nanometric alumina particles with potential conditions to be used in the binding systems of monolithic refractories. However, some parameters needs to be adjusted in future studies in order to improve the results of this preliminary work. 


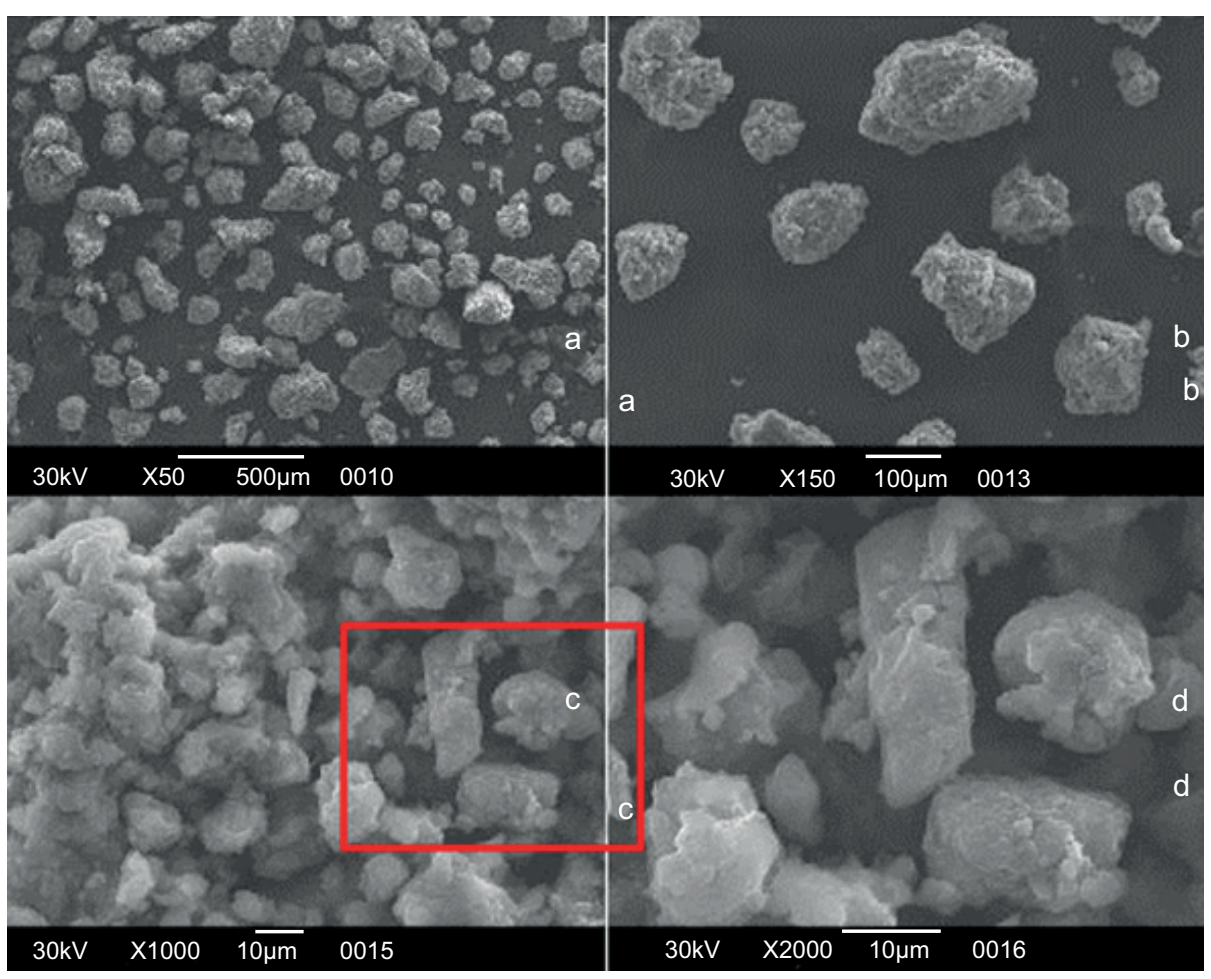

Fig. 4. Morphological evaluation of precursor by scanning electron microscopy.
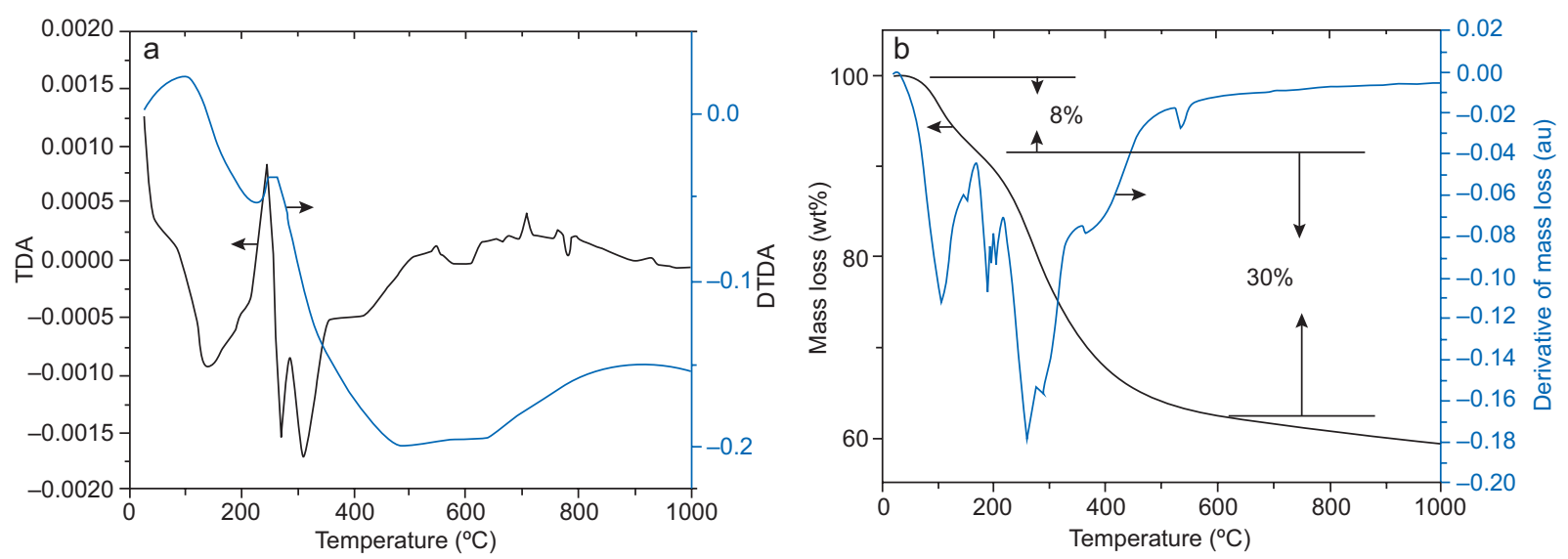

Fig. 5. Thermal evolution of the precursor (a) by thermogravimetric differential analysis (TDA) and derivate thermogravimetric differential analysis (DTDA); (b) by thermogravimetric analysis. 


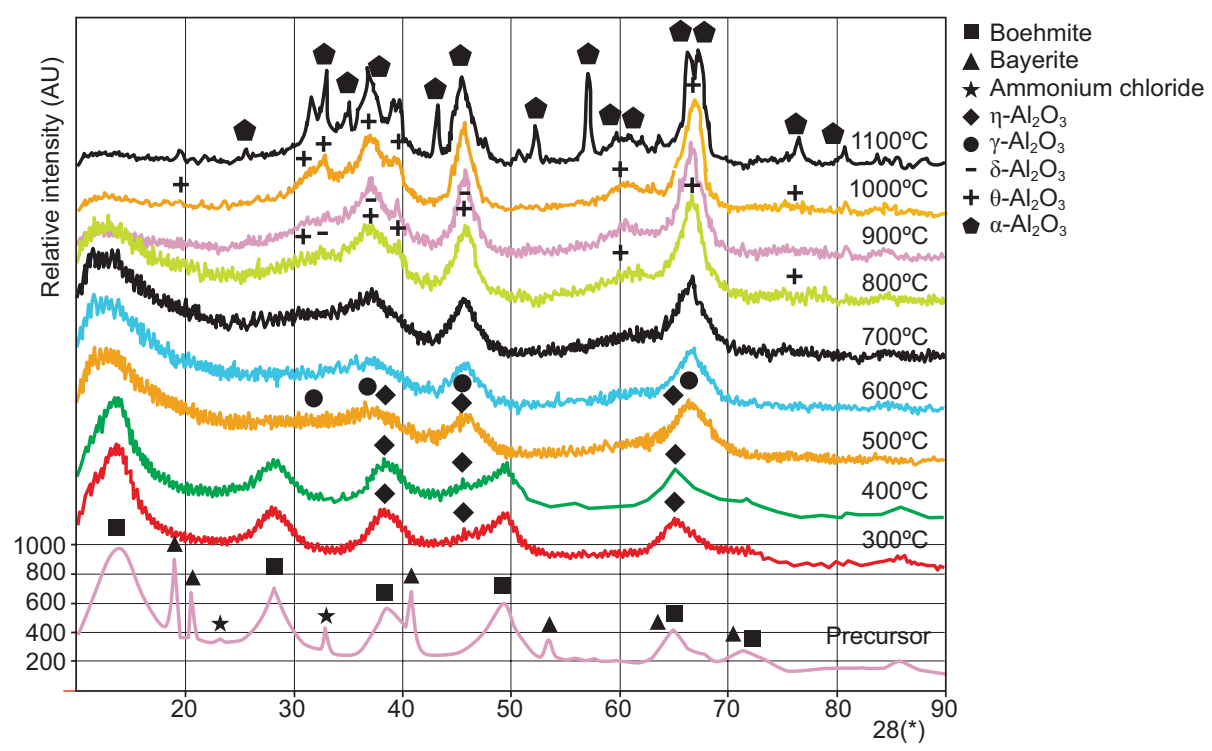

Fig 6. X-ray diffractograms of the thermal evolution of the precursor.

a)

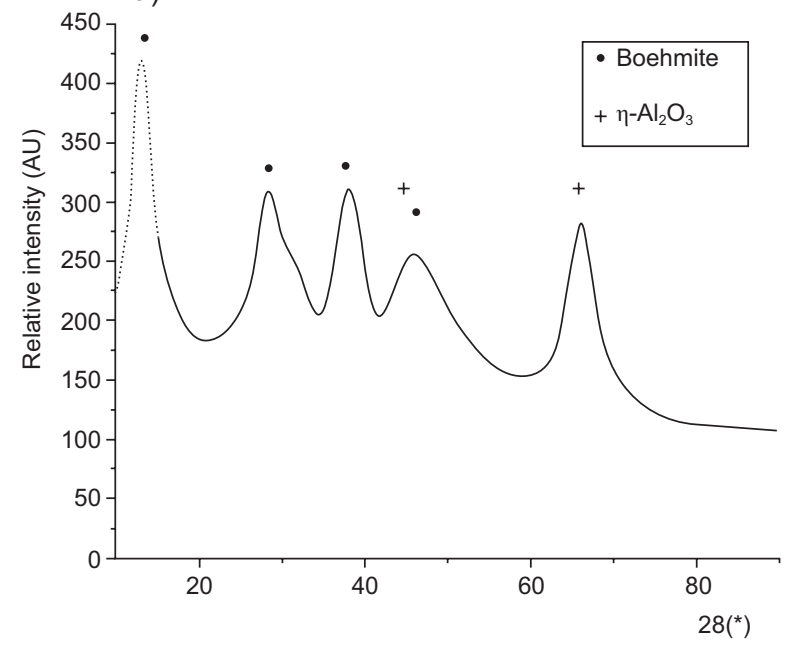

b)

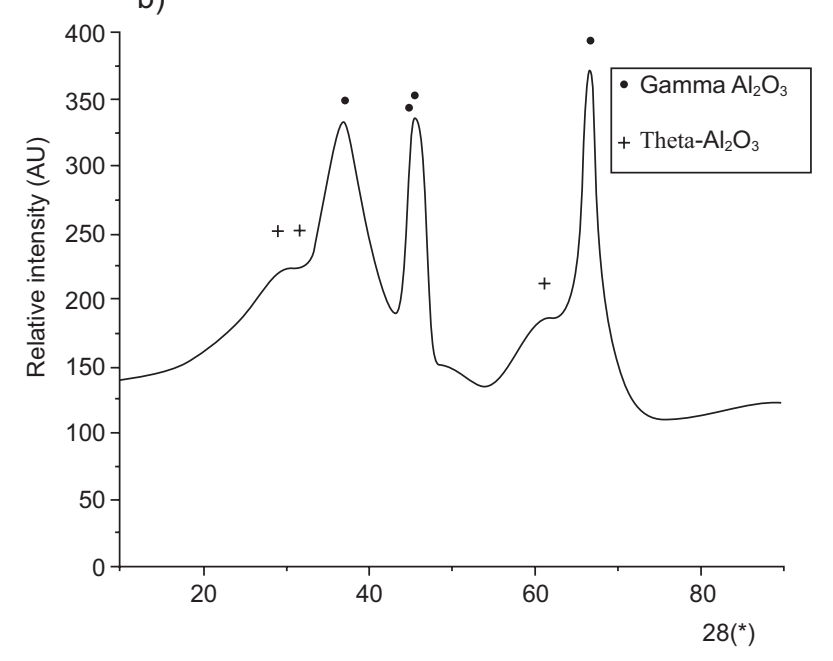

Fig. 7. X-ray diffractograms of synthetized transition alumina at (a) $350{ }^{\circ} \mathrm{C}$ for $4 \mathrm{~h}$; (b) $750{ }^{\circ} \mathrm{C}$ for $4 \mathrm{~h}$.
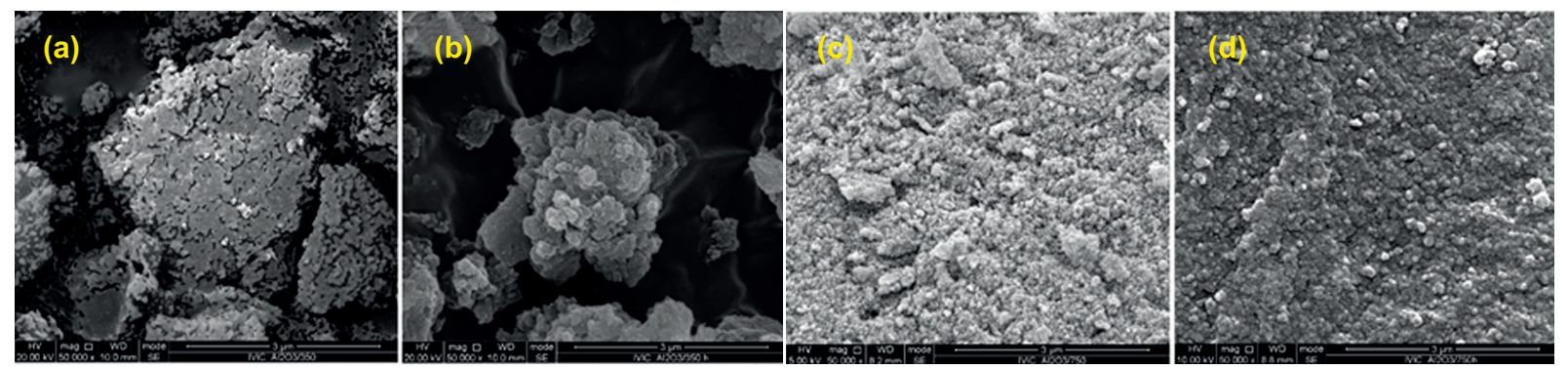

Fig. 8. Photomicrographs of transition aluminas at different conditions: (a) heat-treated at $350{ }^{\circ} \mathrm{C}$ without hydration, (b) heattreated at $350{ }^{\circ} \mathrm{C}$ and hydrated for $168 \mathrm{~h}$, (c) heat-treated at $750^{\circ} \mathrm{C}$ without hydration, (d) heat-treated at $750{ }^{\circ} \mathrm{C}$ and hydrated for $168 \mathrm{~h}$. 


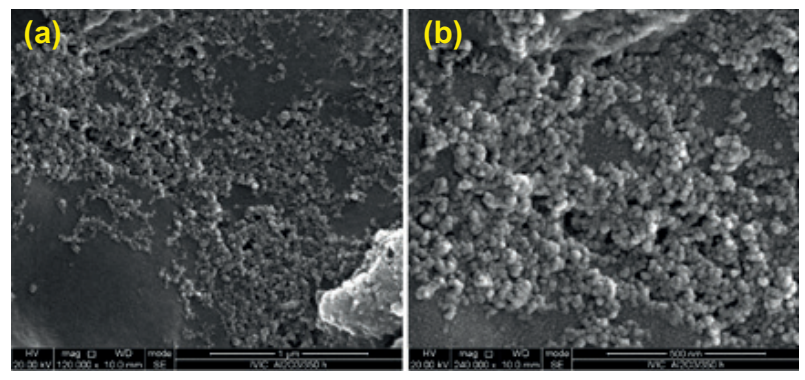

Fig. 9. Photomicrographs of transition aluminas heat-treated at $350{ }^{\circ} \mathrm{C}$ and hydrated for $168 \mathrm{~h}$ : (a) $120.000 \mathrm{X}$ and (b) $240.000 \mathrm{X}$

\section{CONCLUSIONS}

It is possible to synthesize transition aluminas $(\gamma, \eta, \theta)$ from aluminium scrap by using controlled conditions of a wet-chemical route. The presence of the $\rho-\mathrm{Al}_{2} \mathrm{O}_{3}$ phase is not ruled out, due to the amorphous region observed in the diffraction pattern of the sample.

According to the synthesis method, it is possible to obtain transition aluminas in particularly interesting combinations for their application as catalyst supports, activated aluminas or pozzolanic additives for cement. In the near future, these materials could be potential candidates for binding systems in monolithic refractories. Further studies will be conducted to adjust variables in the methodology, for example, the application of washes to remove ammonium chloride.

\section{ACKNOWLEDGMENTS}

We want to acknowledge the Materials Science Department, Universidad Simón Bolívar, and the Chemistry Department, Universidad Metropolitana.

\section{REFERENCES}

Adans Y., Martins A., Coelho R., Das Virgens C., Ballarini A. and Carvalho L. (2016). A simple way to produce $\gamma$-alumina from aluminium cans by precipitation reactions. Mater. Res. 19 (5). https://doi.org/10.1590/19805373-MR-2016-0310

Ahmedzeki N.S., Hussein S. and Abdulnabi W.A. (2017). Recycling waste cans to nano gamma alumina: Effect of the calcination temperature and pH. Int. J. Curr. Eng. Technol. 7 (1), 82-88.
Alphonse P. and Courty M. (2005). Structure and thermal behavior of nanocrystalline boehmite. Thermochim. Acta. 425 (1-2), 75-89. https://doi.org/10.1016/j. tca.2004.06.009

COVENIN (1986). Norma Venezolana COVENIN-2352-86. Aluminio y sus aleaciones. Hoja delgada para la fabricación de envases semirigido. Comité Técnico de Normalización CT8, Materiales Metálicos no Ferrosos, Subcomité Técnico SC1 Aluminio y sus Aleaciones. Comisión Venezolana de Normas Industriales, 10 de junio.

De Souza Santos P., De Souza Santos H. and De Freitas Neves R. (1990). Sobre o envelhecimento em meio aquoso de precipitados de hidróxidos de aluminío tendo dimensoes cooidais. Cerâmica 36, 120-126.

De Souza Santos P, Souza Santos H. and Toledo S. (2000). Standard transition aluminas. Electron microscopy studies. Mater. Res. 3 (4), 104-114. https://doi. org/10.1590/S1516-14392000000400003

Dwivedi R.K. and Gowda G. (1985). Thermal stability of aluminium oxides prepared from gel. J. Mater. Sci. Lett. 4, 331-334. https://doi.org/10.1007/BF00719806

Iesmat (2015).Tecnologías granulométricas [online]. http://www.iesmat.com/Tecnologias-Granulometria. htm 18/10/2018.

Gonzalo L. (2008). Obtención y caracterización de bohemita a partir de un resíduo peligroso de la industria del aluminio. Ph.D. Thesis. Facultad de Ciencias Geológicas, Universidad Complutense de Madrid, Madrid, Spain, 57 pp.

Lee W.E. and Moore R.E. (1998). Evolution of in situ refractories in the 20th century. J. Am. Ceramic. Soc. 81 (6), 1385-1410. https://doi.org/10.1111/j.1151-2916.1998. tb02497.x

Lefévre G., Duc M., Lepeut P., Caplain R. and Fédoroff M. (2002). Hydration of $\gamma$-alumina in water and its effects on surface reactivity. Langmuir 18 (20), 7530-7537. https://doi.org/10.1021/la025651i

Levin I. and Brandon D. (1998). Metastable alumina polymorphs: Crystal structures and transition sequences. J. Am. Ceram. Soc. 81 (8), 1995-2012. https://doi. org/10.1111/j.1151-2916.1998.tb02581.x

López R., Razo N., Pérez T., Hernández O. and Reyes S. (2018). Synthesis of alfa- $\mathrm{Al}_{2} \mathrm{O}_{3}$ from aluminium cans by wet-chemical methods. Results in Physics 11, 1075-1079. https://doi.org/10.1016/j.rinp.2018.11.037

Mahinroosta M. and Allahverdi A. (2018). Enhanced alumina recovery from secondary aluminium dross for high purity nanostructured gamma-alumina powder production: Kinetic study. J. Environ. Manage. 212, 278-291. https://doi.org/10.1016/j.jenvman.2018.02.009

Mahinroosta M. and Allahverdi A. (2018). A promising 
green process for synthesis of high purity activatedalumina nanopowder from secondary aluminium dross. J. Clean. Prod. 179, 93-102. https://doi.org/10.1016/j. jclepro.2018.01.079

Meshram A. and Kumar K. (2018). Recovery of valuable products from hazardous aluminium dross. Resour. Conserv. Recy. (130), 95-108. https://doi. org/10.1016/j.resconrec.2017.11.026

Sato T. (1962). Thermal transformation of alumina trihydrate, bayerite. J. Appl. Chem. 12, 553-556.

Sato T. (2007). The thermal transformation of alumina monohydrate, boehmite. J. Appl. Chem.12 (1), 9-12. https://doi.org/10.1002/jctb.5010121206

Schlesinger M.E. (2007.) Aluminium recycling. 2nd. ed. CRC Press, Portland, USA, 282 pp.

Sharma P. and Varadan V. (2003). A critical role of $\mathrm{pH}$ in the colloidal synthesis and phase transformation of nano size a- $\mathrm{Al}_{2} \mathrm{O}_{3}$ with high surface area. J. Eur. Ceram. Soc. 23, 659-666. https://doi.org/10.1016/ S0955-2219(02)00191-7

Skoog D.,West D., Holler F.J. and Crouch S. (2005) Fundamentos de química analítica. 8a. ed. Cengage Learning, Mexico City, 612 pp.

Smykatz-Kloss W. (1974). Differential thermal analysis, application and results in mineralogy. Springer Verlag, Berlin, New York, USA, 185 pp.

Vitalis (2015). Situación ambiental en Venezuela [online]. https://es.slideshare.net/ONGVitalis/situacin-ambiental-de-venezuela-2015 19/10/2018.

West A.R. (2014). Solid state chemistry and its applications. 2nd ed. John Wiley and Sons, New York, USA, $582 \mathrm{pp}$.

Young R.A. (2002). The Rietveld method. Oxford Science Publications. Oxford University Press, Oxford, UK, 312 pp. 